\title{
O TEMA DA CIÊNCIA NA DIALÉTICA MATERIALISTA
}

\author{
EL TEMA DE LA CIENCIA EN LA DIALÉTICA MATERIALISTA
}

\section{THE SCIENCE THEME IN MATERIALIST DIALECTIC}

DOI: http://dx.doi.org/10.9771/gmed.v11i2.29881

Márcia Morschbacher ${ }^{1}$

\begin{abstract}
Resumo: Este artigo analisa tópicos sobre as condições para a inteligibilidade do real pela ciência a partir da dialética materialista. Abordamos, em uma revisão bibliográfica, a estrutura interna da ciência, a unidade entre fenômeno e essência, o modo de produção como a radicação mais profunda da realidade e alguns pressupostos filosóficos da dialética materialista. Concluímos que: a) a realidade pode e deve ser conhecida; b) a necessidade epistemológica da ciência reside na unidade dialética entre fenômeno e essência; c) a ciência demanda a penetração e a reflexão no pensamento da dinâmica objetiva e concreta da realidade, captando sua conexão interna e sua historicidade.

Palavras-chave: Ciência. Conhecimento. Dialética materialista.
\end{abstract}

Resumen: Este artículo analiza los temas sobre las condiciones para la inteligibilidad de lo real por la ciencia a partir de la dialéctica materialista. Abordamos, en una revisión bibliográfica, la estructura interna de la ciencia, la unidad entre fenómeno y esencia, el modo de producción como la radicación más profunda de la realidade y algunos supuestos filosóficos de la dialéctica materialista. Concluimos que: a) la realidad puede y debe ser conocida; b) la necesidad epistemológica de la ciencia reside en la unidad dialéctica entre fenómeno y esencia; c) la ciencia demanda la penetración y la reflexión en el pensamento de la dinámica objetiva y concreta de la realidade, captando su conexión interna y su historicidade.

Palabras clave: Ciencia. Conocimiento. Dialética Materialista.

Abstract: This paper examines topics about conditions for the intelligibility of the real by science from the materialist dialectic. We approach, in a bibliographic review, the internal structure of science, unity between phenomenon and essence, the mode of production as the deepest root of reality and some philosophical assumptions of the materialist dialectic. We concluded that: a) the reality can and should be known; b) the epistemological necessity of science is in dialectical unity between phenomenon and essence; c) science demands the penetration and reflection in the thought of the objective and concrete dynamics of reality, capturing its internal connection and historicity.

Keywords: Science. Knowledge. Materialist Dialectic.

\section{Introdução}

O presente artigo aborda tópicos sobre o tema da ciência. Tem por objetivo analisar algumas condições para a inteligibilidade da realidade pela ciência (ou os requisitos de cientificidade ao conhecimento) a partir da dialética materialista.

Nosso ponto de partida é o pressuposto de que o desenvolvimento da dialética materialista é realizado por Karl Marx e Friedrich Engels com base na preocupação com uma rigorosa reflexão da realidade no pensamento, de modo a expressá-la como ela efetivamente é e de combater a sua apreensão mistificada ${ }^{2}$ ou limitada 3 . 
O itinerário de Marx e Engels tem como resultado uma concepção científica que serve de instrumental para a análise e explicação da realidade: a dialética materialista. Esta teoria fornece-nos critérios, princípios ou requisitos para a inteligibilidade do real de modo científico ${ }^{4}$.

A dialética materialista é desenvolvida simultaneamente e como resultado da análise rigorosa e crítica da dinâmica da realidade e das mais diversas matérias, tais como a Filosofia, a História, a Economia Política (etc.) e uma intensa atividade política junto ao proletariado. Engels afirma que;

O desenvolvimento da concepção materialista, ainda que fosse a publicação de um único exemplo histórico, foi um trabalho científico que exigiu longos anos de estudo tranquilo, pois é evidente que, aqui, nada se resolve com simples frases, que só a existência de um conjunto de materiais históricos, criticamente selecionados e totalmente dominados, pode capacitar-nos para a solução do problema(ENGELS, 2008, p. 277).

A intensa busca por explicar a realidade material no seu movimento, encontrando nesta a sua radicação fundamental e determinante, a saber, o modo de produção, é o núcleo do itinerário de Marx e Engels. Este tem o seu ápice em “O Capital” com a exposição do estudo do "modo de produção capitalista e as suas relações correspondentes de produção e de circulação” (MARX, 1996, p.130).

Este artigo organiza-se nos seguintes tópicos: a estrutura interna da ciência, a unidade dialética entre fenômeno e essência, o modo de produção como a radicação mais profunda da realidade (tendo como base a produção de Marx até “A Ideologia Alemã”) e alguns pressupostos filosóficos da dialética materialista.

\section{A estrutura interna da ciência}

A ciência é atividade humana realizada com a finalidade de conhecer o mundo e nele intervir, de acordo com as condições materiais e com as necessidades determinadas por essas condições. É atividade que é o reflexo das necessidades materiais humanas e do modo como estas necessidades são prática e materialmente produzidas e providas, em profunda conexão com um dado desenvolvimento das forças produtivas e das relações de produção.

No conjunto das tentativas de explicação da realidade e, a despeito da famigerada relativização das diferentes formas do conhecimento, tratando-as como portadoras de equivalente condição de penetração na realidade, a ciência apresenta uma estrutura interna que a distingue das demais (BARATAMOURA, 1997a). Esta estrutura coloca a ciência como expressão mais desenvolvida dos processos empreendidos pela humanidade para a inteligibilidade do real.

O conhecimento científico supõe a problematização. O dado imediato ou o registro bruto de um dado "não é, ainda não é, sem mais e por si, saber científico” (BARATA-MOURA, 1989, p.45). A ciência conecta-se à resposta a um questionamento determinado, que se refere a um problema com um sentido vital e dramático para a existência humana (SAVIANI, 2009). A cientificidade de um conhecimento refere-se à qualidade da resposta, mas demanda, ainda, a "colocação ajustada das interrogações de vário tipo que estruturadamente possibilitam a sua obtenção" (BARATA-MOURA, 1989, p.45). A problematização permite romper com a imediatez de que um problema pode se revestir na sua aparência. 
Outro traço é a sistematicidade que, necessariamente, estrutura o conhecimento científico. Este exige método: "Saber cientificamente é saber por método, com método. A cientificidade de um saber envolve e empenha consciência de método e proceder metódico” (BARATA-MOURA, 1989, p.46).

A concretização da sistematicidade e do método resulta no saber fundamentado. A sua busca é tarefa da ciência (e da filosofia). Ambas comungam de um "exercício crítico do pensar inquiridor" que o saber fundamentado demanda (BARATA-MOURA, 2009a, p.8, grifo do autor).

A ciência trabalha de forma simultânea com os conhecimentos acumulados, sua crítica e revisão, bem como com a exploração de novas possibilidades explicativas (provisoriedade e desenvolvimento do conhecimento).

A ciência expressa, nos diferentes períodos históricos, o grau de desenvolvimento da capacidade humana de apropriar-se da realidade e explicá-la considerando tanto o legado recebido da geração anterior quanto as condições materiais a partir das quais esta geração produz o viver. O desenvolvimento da ciência avança e/ou retrocede segundo as condições materiais de que é reflexo e nas quais incide.

A penetração racional gradativamente mais profunda na realidade é componente fundamental para a determinação do grau de perenidade e de alcance da ação humana sobre a realidade, seja no quadro imediato da manutenção da existência, seja no revolucionamento do modo de produção.

Dado o enraizamento histórico da ciência, o caminho percorrido para a elaboração das perguntas e das respostas científicas (o método) apresenta limites e possibilidades a uma penetração mais ou menos profunda na realidade e à produção de um conhecimento mais ou menos correspondente com o mundo efetivamente real, tendo em vista as condições materiais da existência.

\section{A necessidade epistemológica da ciência}

A relação entre fenômeno e essência expressa a necessidade epistemológica da ciência ou da elevação do conhecimento à condição de científico (BARATA-MOURA, 1997a). A passagem do capítulo 48 do volume III de “O Capital”, na qual Marx explicita que a ciência seria supérflua se aparência e essência imediatamente coincidissem, reforça essa questão. Tal posição, todavia, se opõe à identidade imediata e empírica entre fenômeno e essência e carrega consigo uma compreensão mais complexa do que a de contraposição.

A identidade imediata entre fenômeno e essência consiste na posição de que o que aparece de imediato aos sentidos e à consciência coincide com a essência do ser. Este princípio é comum tanto ao positivismo e ao empirismo, que reduz o ser à positividade captável empiricamente, quanto ao materialismo feuerbachiano que, no combate ao idealismo de Hegel, identifica o ser com aquilo que é imediatamente sensível. Em ambas as posições, toma-se como essência a manifestação imediata do ser, o que tende a conduzir à apreensão limitada da realidade, porque fora da sua inerente historicidade. Tem-se a exaltação do existente e o fenômeno é apreendido como a "totalidade do próprio ser" (BARATA-MOURA, 1997a).

A segunda posição refere-se à separação entre fenômeno e essência, em que se afirma a diferença entre fenômeno e essência. Este é o pilar das doutrinas idealistas, em que a essência é apreendida em 
dissociação completa ou parcial do fenômeno, seja como um a priori de gênese ideal e autônoma à materialidade do real, seja na condição em que o próprio fenômeno é elevado à essência (BARATAMOURA, 1997a).

No primeiro caso, a essência é autonomizada do ser e torna-se um a priori ou um dever-ser tomado como instância posta à revelia dos processos reais. No segundo, não se alcança, pelo conhecimento, a radicação mais profunda do real ${ }^{5}$.

A posição de Marx sobre a relação entre essência e fenômeno assenta-se em uma base ontológica colocada em contornos distintos. Trata-se de considerar o fenômeno e a essência em unidade dialética. Esta unidade não assoma em uma relação imediata, na qual se apaga a sua diferença, mas em um "processo em que, sendo embora diferentes, constituem, todavia, instâncias diversas de um mesmo movimento, quer do ponto de vista epistemológico, quer do ponto de vista ontológico" (BARATA-MOURA, 1997a, p.81, grifo do autor).

É esta dialeticidade entre fenômeno e essência que permite que, em função da essência ("da estrutura ou razão que o determina naquilo que é na unidade do seu devir” (p.81)), o fenômeno torne-se inteligivel de modo correspondente com a realidade em sua expressão concreta ${ }^{6}$. Isso porque, a forma de manifestação fenomênica do ser corresponde a uma etapa de um processo e, embora também a tenha em si, não exprime as determinações constitutivas da materialidade do ser na sua riqueza.

A realidade, considerada do modo como efetivamente é, não corresponde a um conjunto de elementos isolados e autônomos que cumpre à razão tornar inteligíveis. Esta é um conjunto de relações e processos, dos quais fenômeno e essência constituem instâncias distintas, todavia unas do seu movimento constitutivo (ou seja, da historicidade). A tarefa da ciência é tornar inteligível esta dinâmica material e concreta.

\section{O caminho para a apreensão científica da realidade: a busca da sua radicação determinante}

A base sobre a qual a dialética materialista adquire contornos desenvolvidos é a análise do movimento histórico da realidade, a partir da qual Marx e Engels buscam a sua radicação mais profunda e, uma vez encontrada, voltam os seus esforços a explicá-la em si e na sua conexão interna com o desenvolvimento político, jurídico, filosófico, religioso, etc.

Em “Crítica da Filosofia do Direito de Hegel”, Marx (2012a) coloca em causa o sistema hegeliano ao demonstrar que este aborda o Estado de forma mistificada. Ainda que a crítica não se refira diretamente à base ontológica idealista em que Hegel desenvolve o seu pensamento, mas à política (o Estado), essa já apresenta contornos do desenvolvimento de uma ruptura com a doutrina hegeliana.

O fundamento da crítica assenta-se na inversão operada por Hegel na relação entre Estado e sociedade civil, em que o primeiro é colocado como base da segunda. Para Marx (2010a, p.30): “A ideia é subjetivada e a relação real da família e da sociedade civil com o Estado é apreendida como sua atividade interna imaginária. Família e sociedade civil são os pressupostos do Estado; elas são os elementos propriamente ativos; mas, na especulação, isso se inverte". 
De acordo com a filosofia hegeliana, a sociedade civil é criada pela Ideia Absoluta, é a finitude da Ideia. A sociedade civil deve a sua existência “a um outro espírito" (p.30) e é determinada por este. Para Marx, nestes termos, o predicado torna-se sujeito e o sujeito torna-se predicado, o determinante torna-se o determinado:

Em vez disso, a Ideia é feita sujeito, as distinções e sua realidade são postas como seu desenvolvimento, como seu resultado, enquanto, pelo contrário, a Ideia deve ser desenvolvida a partir das distinções reais. [...] Mas aqui se fala da Ideia como de um sujeito, da ideia que se desenvolve em suas distinções. Além dessa inversão de sujeito e predicado, produz-se aqui a aparência de que o discurso trata de outra ideia que não a do organismo. [...] O "fim do Estado" e os "poderes do Estado" são mistificados, visto que são apresentados como "modos de existência" da "Substância" e aparecem como algo separado de sua existência real, do "espírito que se sabe e se quer", do "espírito cultivado", (MARX, 2010a, p.38).

Hegel "não desenvolve seu pensamento a partir do objeto, mas desenvolve o objeto segundo um pensamento previamente concebido na esfera abstrata da lógica.” (MARX, 2010a, p.36). Marx ainda ressalta: “O momento filosófico não é a lógica da coisa, mas a coisa da lógica. A lógica não serve à demonstração do Estado, mas o Estado serve à demonstração da lógica” (p.39). A busca por aquilo que a realidade é, para Marx, deve se dar na própria realidade.

Em "Para a questão judaica” (1843), Marx opõe-se a Bruno Bauer ao sustentar que: “[...] a religião já não passa por ser o fundamento, mas apenas o fenómeno, da limitação mundana. [...] Nós não transformamos as questões mundanas em [questões] teológicas. Nós transformamos as questões teológicas em [questões] mundanas" (MARX, 1997, p.73, grifo do autor). Para Marx, a emancipação política e a emancipação humana devem ser procurada nas questões mundanas. O limite da emancipação política está no fato de que ainda que o Estado se libertasse de alguma barreira, isso não significa que o ser humano estivesse livre desta: ela subsiste na sociedade civil. Assim, os "direitos do homem" outorgados pelo Estado moderno não são mais que os direitos de liberdade de religião, liberdade de propriedade privada, etc., a afirmação dos interesses do bourgeois sobre os do citoyen.

Marx expressa a sociedade civil como o fundamento (mundano) do Estado. A emancipação política (representada pelo Estado) não corresponde à emancipação humana: esta consiste na supressão da “essência empírica" que perpetua o sistema do dinheiro e do tráfico, a base material do "homem egoísta" e de toda a alienação humana.

Desde a "Crítica da filosofia do direito de Hegel", Marx (2010a) critica a duplicação que o idealismo engendra: entre uma existência material e outra idealizada ou mistificada. Marx observa que o Estado é também suscetível a este fenômeno, se for tomado de forma autonomizada da "sociedade civil". Esta questão é recolocada em "Para a questão judaica", em um patamar superior, quando Marx alcança a radicação do Estado e da sociedade civil, a saber, o "sistema do dinheiro" - que "não é mais do que uma figuração imediata do capitalismo no seu significado e actuação histórico-mundiais" (BARATA-MOURA, 1997b, p.42).

Em "Crítica da filosofia do direito de Hegel - introdução”, Marx (2010b) declara que o homem encontrou "na realidade fantástica do céu" apenas o "reflexo de si mesmo" e necessita "procurar sua autêntica 
realidade" (p.145). Esta realidade é o “mundo do homem, o Estado, a sociedade” (p.145), da qual a religião é o seu produto: "Esse Estado e essa sociedade produzem a religião, uma consciência invertida do mundo, porque eles são um mundo invertido." (MARX, 2010b, p.145, grifo do autor). A tarefa da história e da filosofia:

[...] depois de desaparecido o além da verdade, é estabelecer a verdade do aquém. A tarefa imediata da filosofia, que está a serviço da história, é, depois de desmascarada a forma sagrada da autoalienação [Selbstentfremdung] humana, desmascarar a autoalienação nas suas formas não sagradas. A crítica do céu transforma-se, assim, na crítica da terra, a crítica da religião, na crítica do direito, a crítica da teologia, na crítica da política (MARX, 2010b, p.146, grifo do autor).

Se Marx ainda não nomeia o modo de produção como a base do “mundo do homem” e identificao limitadamente com a sociedade, a política e o Estado, as perguntas sobre o que é este mundo e como é engendrado, além do reconhecimento da possibilidade de que estes componentes também pereçam de uma "constitutiva duplicação de mundos", constituem pontos de apoio para o salto determinante ao desenvolvimento do pensamento de $\mathrm{Marx}^{7}$.

Em "Crítica à filosofia do direito de Hegel - introdução", na análise da situação política e econômica alemã, que se encontra em anacronismo com a Inglaterra e a França, Marx (2010b) pontua que, não obstante o desenvolvimento da filosofia alemã, esta é também o resultado deste descompasso. A resolução do anacronismo demanda "tarefas para cujas soluções há apenas um meio: a prática” (MARX, 2010b, p.151, grifo do autor). Esta tarefa, entretanto, não se situa unicamente em "energia revolucionária e autossentimento [Selbstgefüh] espiritual” (MARX, 2010b, p.154):

A arma da crítica não pode, é claro, substituir a crítica da arma, o poder material tem de ser derrubado pelo poder material, mas a teoria também se torna força material quando se apodera das massas. A teoria é capaz de se apoderar das massas tão logo demonstra ad hominem, e demonstra ad hominem tão logo se torna radical. Ser radical é agarrar a coisa pela raiz. Mas a raiz, para o homem, é o próprio homem. [...] A crítica da religião tem seu fim com a doutrina de que o homem é o ser supremo para o homem, portanto, com o imperativo categórico de subverter todas as relações em que o homem é um ser humilhado, escravizado, abandonado desprezível. [...] As revoluções precisam se um elemento passivo, de uma base material (MARX, 2010b, p.151-152, grifo do autor).

As "massas" são o proletariado, que Marx caracteriza como uma classe da sociedade civil que é a dissolução dessa sociedade, pois seus interesses são universais; a classe que "é, numa palavra, a perda total da humanidade e que, portanto, só pode ganhar a si mesma por um reganho total do homem" (MARX, 2010b, p.156, grifo do autor).

Nesta etapa do pensamento de Marx, a base material sobre a qual se assentam as possibilidades de revolucionamento da realidade ainda aparece como algo de passivo. Os "Manuscritos de 1844" expressam o movimento em direção à superação deste aspecto.

Compreendemos que o caminho que Marx percorre na direção da crítica da Economia Política ${ }^{8}$ e que se expressa já nos "Manuscritos de 1844", marca decisivamente a busca pela radicação mais profunda da realidade, cujo conteúdo será determinante a todo o desenvolvimento ulterior da dialética materialista e da explicação científica do modo de produção capitalista.

Os "Manuscritos de 1844" contemplam a crítica aos economistas clássicos e a tentativa de Marx explicar a situação em que se encontra o proletariado no capitalismo. A elucidação da base material sobre a 
qual radica a realidade, cujo patamar da política revela-se insuficiente, se expressa na crítica da Economia Política. Trata-se de uma tarefa inadiável, posto que é esta base material que necessita ser revolucionada.

Diferentemente de Feuerbach, Marx desenvolve um itinerário em direção a captar a historicidade do ser - o que se relaciona com a dialética hegeliana. Marx atribui a Hegel o limite de ter concebido a positividade como exteriorização da Ideia. Entretanto, também reconhece o mérito de Hegel em ressaltar a "autoprodução do homem". Hegel "compreende a essência do trabalho e concebe o homem objetivo, verdadeiro, porque homem efetivo, como o resultado de seu próprio trabalho" (MARX, 2004, p.123, grifo do autor), ainda que estes aspectos apareçam como o resultado da exteriorização do Espírito.

Nos "Manuscritos de 1844", o mundo é explicado como o resultado da ação humana, em uma análise que vai do ser humano abstrato (ao mesmo tempo pertencente e estranhado do seu gênero) ao concreto (o trabalhador que é obrigado a suportar as agruras de um modo de produção em que a efetivação do trabalho é a sua desefetivação). Marx (2004) situa o trabalho como categoria sem a qual a apreensão da conexão entre natureza, homem e história é limitada. Estes três componentes passam a ser concebidos na conexão que lhes é constitutiva.

A natureza constitui o substrato primigênio a partir do qual o ser humano assegura a sua subsistência e efetiva a si mesmo. Pelo trabalho, o ser humano transcende a condição natural da realidade e converte-a em "uma parte da vida humana e da atividade humana" (MARX, 2004, p.84).

O ser humano desenvolve a sua universalidade ao se elevar sobre a natureza em uma relação dialética entre o natural e o socialmente produzido. A sociedade produz o homem enquanto homem e é produzida por ele. As condições materiais que estão na base do desenvolvimento da sociedade são o resultado da ação humana. O trabalho representa, assim, um elemento chave para compreender a historicidade da realidade.

No sistema capitalista, a atividade que é meio de efetivação do trabalhador torna-se meio de sua desefetivação. A base material desta desefetivação, que estranha o ser humano do produto e do processo de produção, de si mesmo e do seu "gênero", é a propriedade privada. Marx identifica na relação que o trabalhador estabelece com a produção, a raiz da "opressão humana inteira" (MARX, 2004, p.88). A ação programática que objetiva a emancipação humana consiste na superação da propriedade privada (MARX, 2004).

Considera-se que "A ideologia alemã" representa a expressão mais desenvolvida, até então, da busca pela radicação da realidade para a sua apreensão e explicação científica: trata-se de captar o movimento real do modo de produção capitalista considerando as suas leis e o seu movimento.

Nesta obra, a produção e reprodução da existência é apreendida como o pressuposto de toda a história. Nesse processo são desenvolvidas determinadas formas de relações sociais independentes da vontade humana. A cada nível de desenvolvimento das forças produtivas, correspondem determinadas relações de produção, que retroagem sobre as forças produtivas (MARX; ENGELS, 2007, p.34).

Marx e Engels apreendem a conexão entre os diferentes períodos históricos, em que cada modo de produção refere-se ao modo de produzir e reproduzir a vida necessário ou possível a um determinado grau de desenvolvimento das forças produtivas e que está sujeito a perecer. Estes modos de produção 
carregam consigo o gérmen da sua própria derrocada: as relações de produção, que impulsionavam o desenvolvimento das forças produtivas, convertem-se em seu entrave e tem-se um período de revolução social, em que novas relações de produção são engendradas em correspondência com forças produtivas mais desenvolvidas (MARX, 2008).

O modo de produção da existência é a base sobre a qual se desenvolvem determinadas formas de organização da sociedade e todo o sistema de ideias (políticas, jurídicas, filosóficas, artísticas, religiosas, etc.). Elucidar estas formas de organização social e o sistema de ideias demanda abordá-los na sua conexão interna com o modo de produção e de reprodução da existência:

O fato é, portanto, o seguinte: indivíduos determinados, que são ativos na produção de determinada maneira, contraem entre si estas relações sociais e políticas determinadas. A observação empírica tem de provar, em cada caso particular, empiricamente e sem nenhum tipo de mistificação ou especulação, a conexão entre a estrutura social e política e a produção. A estrutura social e o Estado provêm constantemente do processo de vida de indivíduos determinados, mas desses indivíduos não como podem aparecer na imaginação própria ou alheia, mas sim como realmente são, que dizer, tal como atuam, como produzem materialmente e, portanto, tal como desenvolvem suas atividades sob determinados limites, pressupostos e condições materiais, independentes de seu arbítrio. A produção de ideias de representações, da consciência, está, em princípio, imediatamente entrelaçada com a atividade material e com o intercâmbio material dos homens, com a linguagem da vida real. [...] Os homens são os produtores das suas representações, de suas ideias e assim por diante, mas os homens reais, ativos tal como são condicionados por um determinado desenvolvimento de suas forças produtivas e pelo intercâmbio que a ele corresponde, até chegar às suas formações mais desenvolvidas. A consciência [Bewusstsein] não pode jamais ser outra coisa do que o ser consciente [bewusste Sein], e o ser dos homens é o seu processo de vida real. (MARX; ENGELS, 2007, p.93-94).

Esta relação opera-se no quadro de uma relação recíproca entre o modo de produção e de reprodução da vida real e os componentes da superestrutura. O elemento determinante, decisivo e que engendra materialmente a superestrutura são as condições materiais de existência, no entanto, esta superestrutura interfere sobre esta base material ${ }^{9}$.

A compreensão científica da realidade coloca como tarefa precípua, portanto, apreender as leis internas do modo de produção capitalista - acompanhando o movimento interno de gênese, desenvolvimento e tendências de derrocada - para, a partir deste e simultaneamente, elucidar a conexão interna e a relação recíproca com a superestrutura. Esta questão além de, portar contornos ontológicos e gnosiológicos decisivos, apresenta-se determinante também à intervenção prática do proletariado na direção da superação do modo de produção capitalista: esta transformação é um movimento prático, engendrado no interior do próprio modo de produção e que o proletariado impulsiona.

\section{Pressupostos filosóficos e condições de cientificidade ao conhecimento}

Os traços de uma concepção materialista e dialética da realidade encontram-se (embora aquém do seu desenvolvimento ulterior) na crítica de Marx a Hegel em "Crítica da Filosofia do Direito de Hegel”. Esta crítica leva-o a afirmar que a investigação da realidade deve proceder à análise da "lógica da coisa", ou seja, deve analisar o ser efetivamente real, na sua lógica interna, na composição que lhe é inerente ou própria. 
A ênfase na necessidade da atenção à lógica da coisa carrega consigo implicações ontológicas e gnosiológicas em que o problema da historicidade está contido, mas não consequentemente desenvolvido.

A referência, em "Para a questão judaica", ao sistema do dinheiro e do tráfico como a base da sociedade civil e o posterior itinerário de Marx e Engels para determinar as leis de funcionamento deste sistema, indicam o importante papel do princípio acima aludido. A investigação do Estado e da sociedade civil em sua lógica, permite a Marx avançar em direção às determinações mais profundas da sociedade civil e identificar no modo de produção capitalista a sua base.

Outro patamar deste desenvolvimento, em "Para a questão judaica" e em "Crítica da filosofia do direito de Hegel - introdução", é a evidência de que a religião e a política (e demais componentes da superestrutura) devem ser investigadas tendo em conta o mundo que as produz e que as faz subsistir (MARX, 2010b).

Este é um aspecto decisivo, pois a necessidade de que este mundo seja rigorosamente investigado apresentará como caminho incontornável o estudo da Economia Política. Ademais, é um aspecto fundamental à direção da intervenção prática para a transformação da realidade, que deve se voltar para a transformação das condições materiais.

Embora a concepção materialista de Feuerbach apareça como importante base a partir da qual Marx funda as posições materialistas que sustenta neste período, a apropriação do materialismo feuerbachiano dá-se em patamares de criticidade. Esta relação com a posição materialista de Feuerbach não reduz, contudo, a sua importância enquanto suporte ontológico de que Marx se utiliza para engendrar a crítica ao idealismo alemão ${ }^{10}$.

A crítica de Feuerbach ao sistema filosófico hegeliano é acompanhada do despedimento do seu núcleo racional: a dialética; o que leva-o a limitar a sua concepção materialista da realidade à contemplação do mundo sensível, que não é, ademais, apreendido na forma de "atividade bumana sensivel" (MARX; ENGELS, 2007, p.533). Resulta disso a apreensão da realidade na sua imediatez e destituída de historicidade, o que autoriza Feuerbach a manter subsistentes abstrações como "o homem" ou "a natureza" 11 . De acordo com Marx e Engels.

Ele não vê como o mundo sensível que o rodeia não é uma coisa dada imediatamente por toda a eternidade e sempre igual a si mesma, mas o produto da indústria e do estado de coisas da sociedade, e isso precisamente no sentido de que é um produto histórico, o resultado da atividade de toda uma série de gerações, que, cada uma delas sobre os ombros da precedente, desenvolveram sua indústria e seu comércio e modificaram sua ordem social de acordo com as necessidades alteradas (MARX E ENGELS 2007, p. 30).

Pelo exposto, a concepção materialista da realidade é uma concepção com um conteúdo distinto do materialismo limitado à celebração da positividade imediatamente apreensível pelos sentidos. A dialética, rigorosa e criticamente analisada por Marx e Engels para desembaraça-la do idealismo hegeliano, tem papel central na configuração de uma concepção materialista que coloque como questão essencial para a apreensão do ser a dialeticidade que lhe é constitutiva e que é determinante ao seu conteúdo. Engels (1985a, p.405) expressa: "Hegel não foi simplesmente posto de lado; partiu-se, pelo contrário, do seu lado revolucionário acima desenvolvido, do método dialéctico. Mas, este método, na sua forma hegeliana, era inutilizável”. 
Hegel capta o movimento real da realidade, apesar da mistificação que sofre este movimento e a própria realidade. Marx e Engels eliminam a inversão operada por Hegel e mantêm o seu núcleo racional, portador de sentido histórico e revolucionário ${ }^{12}$. Marx (1996) ressalta este aspecto ao delimitar que, em sua forma mistificada, "a dialética foi moda alemã porque ela parecia tornar sublime o existente” (p.141), nas, na sua configuração racional, causou horror à burguesia e seus ideólogos, pois: “[...] no entendimento positivo do existente, ela inclui ao mesmo tempo o entendimento da sua negação, da sua desaparição inevitável; porque apreende cada forma existente no fluxo do movimento, portanto, também com seu lado transitório; porque não se deixa impressionar por nada e é, em sua essência, crítica e revolucionária” (p. 141).

Uma vez desembaraçada de seus supostos idealistas, a unidade da dialética e do materialismo resulta, no plano da ontologia, em uma concepção mais rica da realidade que abrange o ser naquilo que ele efetivamente é: materialidade que devém, que se tece e entretece. A dialética é constitutiva, inerente à materialidade do ser (BARATA-MOURA, 2009b). No plano gnosiológico, eleva-se, portanto, a imprescindibilidade de que a investigação da realidade reflita o ser a partir da historicidade que lhe é materialmente constitutiva. Esta é a tarefa da ciência.

É necessário captar a materialidade do ser não apenas como "coisidade", mas, também, como processo e como relação que têm em sua base o contínuo ato humano de produção e reprodução da existência ${ }^{13}$. Assim, a dialética é concebida simultaneamente como processo objetivo que é inerente à materialidade do ser e como reflexo consciente do movimento dialético do mundo real. A historicidade é constitutiva da materialidade do ser. Não consiste em elemento proveniente da subjetividade humana que lhe é acrescido no decurso da investigação (BARATA-MOURA, 2009b). Trata-se de uma "nova qualidade da materialidade"14, que abrange os processos objetivos que operam e constituem o ser. E a dialética materialista revela-se, simultaneamente, como concepção e como instrumental capaz de refleti-la no pensamento.

Considerar a historicidade como princípio fundamental a ser apreendido no processo de conhecimento da realidade coloca, por um lado, a condição objetiva do caráter histórico da realidade e, por outro, permite captar a conexão interna dos fenômenos. Esta, sob o pressuposto materialista e dialético, refere-se a um processo objetivo e constitutivo da materialidade do ser.

\section{Conclusão}

Sendo o conhecimento científico um conhecimento com uma dada estrutura interna, cumpre-nos associar a este entendimento componentes informados pela dialética materialista e que buscamos apresentar neste manuscrito.

A cientificidade do conhecimento, tendo em conta os pressupostos ontológicos e gnosiológicos da dialética materialista, refere-se de modo decisivo com a penetração e reflexão no pensamento da dinâmica objetiva da realidade. A ciência é a expressão teórica (reflexo no pensamento) da materialidade deveniente do real.

Dito de outro modo, a ciência tem como tarefa precípua refletir de modo rigoroso os estágios de desenvolvimento, os processos objetivos e a conexão interna que são determinantes para a configuração do ser. Esta é a 
condição principal para atender à necessidade epistemológica da ciência, que diz respeito à unidade dialética entre fenômeno e essência. Neste processo, a conexão com a radicação mais profunda da realidade, o modo de produção, é condição vital à produção do conhecimento científico.

O empreendimento científico deve assentar-se em solo materialista. Todavia, um materialismo na sua expressão mais desenvolvida - dialético. Assim, a dialética materialista somente é concebida na sua riqueza e possibilidade de explicar a realidade e somente é utilizada no processo de conhecimento da realidade em toda a sua amplitude e profundidade, se e quando, dialética e materialismo são tomados na sua unidade intrínseca.

\section{Referências}

BARATA-MOURA, J. A dialéctica da cientificidade: algumas reflexões para debate. Vértice, Lisboa, n.20, p.43-50, nov.1989.

A filosofia, a ciência, e o pensar. Lisboa, jan. 2009a. Mimeo.

Materialismo e subjectividade: estudos em torno de Marx. Lisboa: Avante, 1997a.

$2009 \mathrm{~b}$.

. Materialismo e dialéctica, ou da ontologia em Marx. Vértice, Lisboa, n.145, p.5-16, mar./abr.

. Uma introdução a Zur Judenfrage de Karl Marx. In: MARX, K. Para a questão judaica. Tradução José Barata-Moura. Lisboa: Avante, 1997b. p.9-63.

ENGELS, F. Comentários sobre a Contribuição à Crítica da Economia Política, de Karl Marx. In: MARX, K. Contribuição à crítica da economia politica. Tradução Florestan Fernandes. 2.ed. São Paulo: Expressão Popular, 2008. p.273-285. 1981.

Do socialismo utópico ao socialismo cientificico. Tradução Roberto Goldkorn. 4.ed. São Paulo: Global,

. Ludwig Feuerbach e o fim da filosofia clássica alemã. In: MARX, K; ENGELS, F. Obras escolbidas em três tomos. t.3. Lisboa: Avante, 1985a. p.378-421.

. Carta de Friedrich Engels a Joseph Bloch (21-22 de setembro de 1890). In: MARX, K.;

ENGELS, F. Obras escolbidas em três tomos. t.3. Lisboa: Avante, 1985b. p.547-549.

Carta de Friedrich Engels a Conrad Schmidt (5 de agosto de 1890). In: MARX, K.; ENGELS, F. Obras escolbidas em três tomos. t.3. Lisboa: Avante, 1985c. p.542-544.

. Carta de Friedrich Engels a Conrad Schmidt (27 de outubro de 1890). In: MARX, K.; ENGELS, F. Obras escolbidas em três tomos. t.3. Lisboa: Avante, 1985d. p.549-556.

. Carta de Friedrich Engels a Franz Mehring (14 de julho de 1983). In: MARX, K.; ENGELS, F. Obras escolbidas em três tomos. t.3. Lisboa: Avante, 1985e. p.556-561.

. Carta de Friedrich Engels a W. Borgius (25 de janeiro de 1894). In: MARX, K.; ENGELS, F. Obras escolbidas em três tomos. t.3. Lisboa: Avante, 1985f. p.565-567.

MARX, K; ENGELS, F. A ideologia alemãa. Tradução Rubens Enderle, Nélio Schneider, Luciano Cavino Martorano. São Paulo: Boitempo, 2007.

MARX, K. Carta de Marx a J. B. Von Schweitzer (24 de janeiro de 1865). In: MARX, K. A miséria da filosofia. Tradução José Paulo Netto. São Paulo: Global, 1985. p.217-225.

Contribuição à crítica da economia política. Tradução Florestan Fernandes. 2.ed. São Paulo: Expressão Popular, 2008.

Crítica da filosofia do direito de Hegel. Tradução Rubens Enderle e Leonardo de Deus. 2.ed. São

Paulo: Boitempo, 2010a. 
Crítica da filosofia do direito de Hegel - Introdução. In: MARX, K. Crítica da filosofia do direito de Hegel. Tradução Rubens Enderle e Leonardo de Deus. 2.ed. São Paulo: Boitempo, 2010b. p.145-157. Manuscritos econômico-filosóficos. Tradução Jesus Ranieri. São Paulo: Boitempo, 2004. . Para a questão judaica. Tradução José Barata-Moura. Lisboa: Avante, 1997.

O capital: crítica da economia política. Tradução Regis Barbosa e Flávio Kothe. São Paulo: Nova Cultural, 1996. v.1.

SAVIANI, D. Educação: do senso comum à consciência filosófica. 18.ed. Campinas: Autores Associados, 2009.

\section{Notas:}

1 Doutora em Educação pela Universidade Federal da Bahia. Mestre em Educação Física pela Universidade Federal de Pelotas. Docente do Departamento de Metodologia de Ensino do Centro de Educação da Universidade Federal de Santa Maria. Coordenadora Substituta do GTT Formação Profissional e Mundo do Trabalho do Colégio Brasileiro de Ciências do Esporte (CBCE). Pesquisadora do Grupo LEPEL/FACED/UFBA. Os estudos de Doutorado foram realizados com financiamento dos Programas de Bolsas CAPES/DS e Capes PDSE (Processo no BEX 12885/13-4). ORCID: http://lattes.cnpq.br/5642933732629148 Email: mm.edufisica@yahoo.com.br

2 Ver o debate de Marx e Engels (2007) com os jovens hegelianos em "A Ideologia Alemã".

3 A identificação da ciência com a apreensão dos fatos tal como aparecem imediatamente à experiência sensível, corresponde a um limitado processo de apreensão do real (BARATA-MOURA, 1997a).

${ }^{4}$ Engels (1985c, p.543-544) afirma: “A nossa concepção de história, porém, é, antes de tudo, uma directiva [Anleitung] para o estudo, [não é] nenhuma alavanca de construções à la hegelianos [Hegelianertum]. A história tem se de ser estudada de novo, as condições de existência [Daseinsbedingungen] das diversas formações sociais [Gesellschaftsformationen] têm que ser investigadas em pormenor, antes de tentar deduzir a partir delas os modos de ser [Anschanungsweise] políticos, de direito privado, estéticos, filosóficos, religiosos, etc, que lhes correspondem".

5 Tomemos como exemplo "Para a Questão Judaica", em que Marx (1997) identifica o equívoco de Bruno Bauer ao vincular a emancipação política à supressão da religião no/do Estado. Bauer toma a religião como a radicação essencial da não liberdade civil, que, para Marx, encontrar-se-ia em um patamar mais profundo.

${ }^{6}$ Ver o exemplo anteriormente referido no debate com Bruno Bauer sobre a questão judaica. Marx transpõe os limites do aparente e busca explicar a raiz da emancipação na essência do Estado e da sociedade civil.

7 O período em que Marx elabora "Para a Questão Judaica" e "Crítica da filosofia do direito de Hegel - introdução" corresponde à sua estada em Paris entre 1843 e 1845. Marx estabelece relações com o proletariado na França, com Engels e estuda Economia Política.

${ }^{8}$ Este movimento, em Engels, é o ensaio "Esboço de uma crítica da Economia Política".

${ }^{9}$ Ver Engels (1985b; 1985d; 1985e; 1985f).

10 Ver Marx (2004; 1985), Engels (1985a) e Marx e Engels (2007).

${ }^{11}$ Feuerbach fica sujeito a semelhante resultado ao tomar o mundo sensível abstratamente. Ao não conceber o mundo sensível como resultado da atividade prática material e elevá-lo como idêntico a si mesmo pela eternidade, este constrói um "mundo" autônomo que sobrepaira ao mundo efetivamente real. Ver Marx e Engels (2007) e Engels (1985a).

12 Ver Engels (2008; 1981; 1985a) e Marx (1996).

13 Outro ponto quanto à "nova qualidade" da materialidade é o seu contributo na investigação do modo de produção capitalista e da elucidação do capital como relação social objetiva resultante de um conjunto de relações e processos também objetivos.

14 Ver Barata-Moura (1997a). 